ESSAYS

Invited article

Original version

DOI: http://dx.doi.org/10.159o/So034-759020180314

\title{
OF POROTOS AND BEANS
}

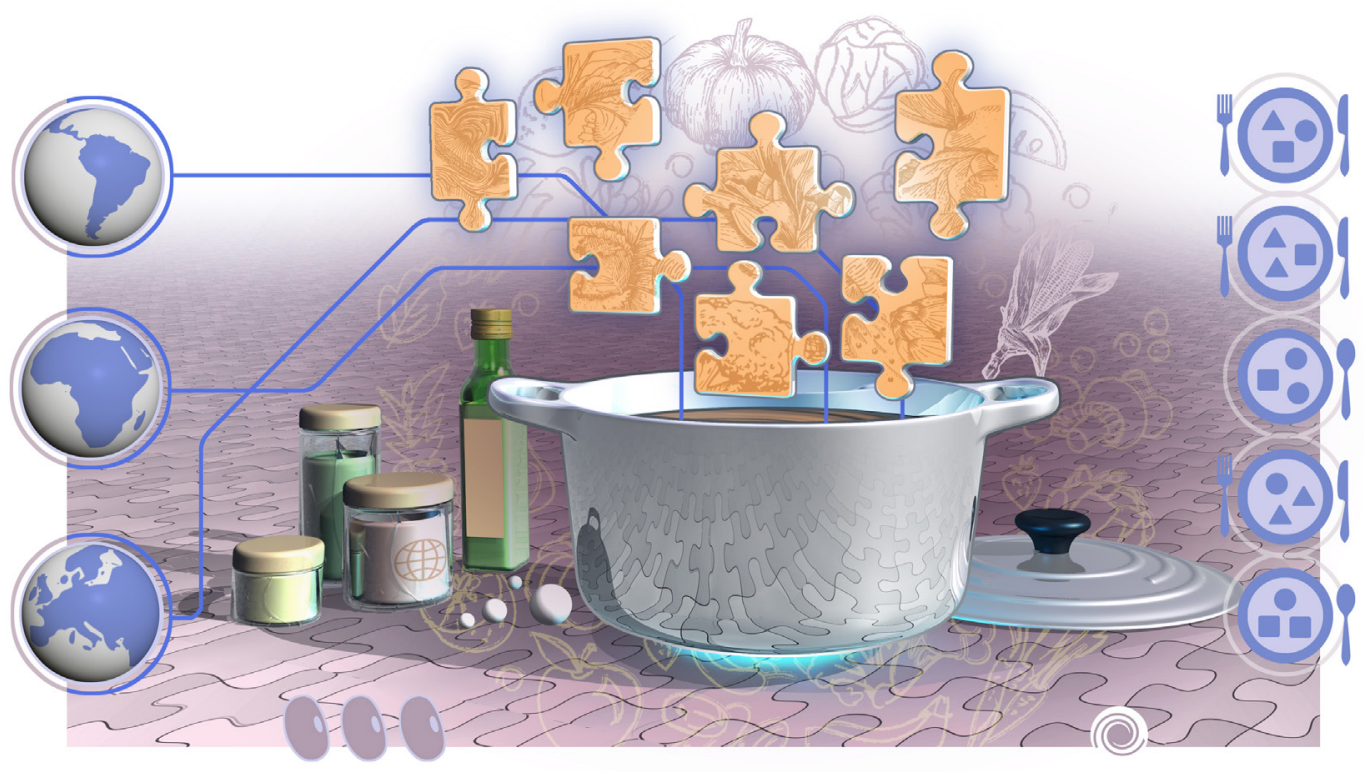

Academic studies have tried to bring to light the process of establishing a national narrative on cuisine, focusing mainly on how the clash between the upper class and the popular cuisine is presently affected throughout the construction of a new perception of history (Bornand, 2012). In general terms, even more homogeneously than it may seem at first glance, there is a prevailing thesis on the formation of Latin-American national cuisines which claims that these are miscegenated entities. It claims, in Brazil's case, that indigenous and African recipes have been assimilated and improved through the adoption of European techniques, creating the national cuisine. Even in the case of excolonies, the highlight is given invariably to the dominance of adoption processes of European techniques, as in a global adaptation of western cuisine itself. Thus, as far as preparation is concerned, native cultures are subjects in a "disappearance" process, only seen by the few marks they leave in the ever-increasing globalization. The importance given to corn in the Americas is a great example, with original techniques of its handling being overshadowed, such as in the case of nixtamalization among the Mexican peoples. This is explainedfundamentally-by the contradictory necessity of the Crioulo elite to trace back its roots to the

\section{CARLOS ALBERTO DÓRIA}

cadoria2@gmail.com

${ }^{1}$ Faculdade das Américas, São Paulo, SP, Brazil West, at the same time it links itself to its native culture. A "deaf opposition" between "community" and "society," or Gemeinschaft-Gesellschaft dichotomy as proposed by Tonnies (1961), seems to be the theoretical background that informs the analyses which are accomplices to the nationalistic discourse. 
The idea of "convergence" is what truly leads this narrative strategy, in a way that a new understanding of this part of the Westcreated by colonialism-is achieved. Among Brazilians, for instance, two narratives had been imposed in the $20^{\text {th }}$ century: the mixture of natives, blacks, and whites (Cascudo, 1997) and the convergence of "regions" around a single national body (Freyre, 1946), with a highlight to the so-called leading and unifying contribution of the Portuguese. From this perspective, the Crioulo cuisine, or the national cuisine, is the destination of the concrete historical adventure. From the perspective of food that comprises vast territories, it is also important to consider the early diffusionist theories which were dear to those who suffered great influence of theoreticians like Franz Boas, as did Gilberto Freyre. To Boas (1966), diffusion is a phenomenon that is observed from polar types and, by induction, admits the existence of intermediate types. In his words,

The introduction of new ideas must by no means be considered as resulting purely mechanically in addition to the cultural pattern, but also as an important stimulus to new inner developments. A purely inductive study of ethnic phenomena leads to the conclusion that mixed cultural types that are geographically or historically intermediate between two extremes give evidence of diffusion. (p. 291)

Thus, miscegenation (historical development) and diffusionism are our theoretical problems, though there is common ground between them: the pure types disappear throughout history.

But this is no simple theoretical question to anthropology. After the assembling and musealization of a series of artifacts from cultures around the world, the West saw itself in charge of deciding if those assimilated had been originated from parallel development or from diffusion. These ar- tifacts were grouped according to families, genus, and species as if they were natural things, ordered in sequences that highlighted the change from simplicity into complexity in accordance with rationalism that claimed that in culture, just as in nature, like effects implied like causes. Facing this, Boas (1966) notably points out the lack of studies that related any cultural traces of a people to the other elements of that same culture, before considering diffusion or evolution. And this diffusion should also respect the limited scope of contact among neighboring peoples, that is, from a same "geographical province"-in some way relatives. Besides these features in common, Boas (1966) recognized the original independent development, but it all needed to count on a scrupulous differentiation of the elements being studied. Thus, he faces the discussion of cultural features that had evolved through their own means and from a common starting point. Therefore, through Boas' method (1966), it was first necessary to have available comprehensive information of a tribal people, followed by the historical analysis of neighboring groups and their contacts, in a way that assumptions could be made about the origin and distribution of some cultural features in order to search for laws of cultural development that ended up being, invariably, those of diversity and differentiation from the same origin. For more details, consult Martínez-Hernáez, A. (2011), El dibujante de limites: Franz Boas y la (im)posibilidad del concepto de cultura en antropologia.

However, coming back to our problem-that of eating practices-we must recognize that the territorialist/local idea in which is embedded the notion of terroir, such as to determine the quality of foodstuffs. The human work is subsumed by the ecosystem, or something similar, and "history" is of little use as an instance of determination of concrete forms. That is, this notion of terroir "naturalizes" human work as well as history (Dória, 2009). On a differ- ent note, it is self-evident that we can outline a cuisine from the dispersion of certain ingredients over a territory, but that will be a rough depiction because when we focus on a dish, each one of the ingredients such as biomes is not important. What matters is how this dish is made, and how, in a single dish, a plurality of ingredients is gathered, associated in a persistent form, being re-signified across time and space. Besides, we must recognize that insofar as building a nation's culinary identity is concerned, we need to be alert to the century-long process of selection of and fixation on ingredients, farming methods, cooking techniques, and popular eating habits, which at a given moment are promoted to a symbolic expression that connects them with the Nation-State.

Tilly (1992) had already called attention to how authoritative the construction of a Nation-State (e.g., language, religion, education) is-and this is no different when eating practices are concerned. If we observe the behavior of Latin-American elites in the $19^{\text {th }}$ century, we can easily notice the diffusion of French culture throughout the way of speaking and writing, as well as the consumption of the most common products, etiquette at the table and long-lasting taste preferences. This globalization of taste, and consequently its standardization, echoed across former colonies, where Crioulo elites "internationalized" themselves.

However, this is not how the lower classes behaved. It suffices to observe the persistence in localisms and old habits which prove their nonparticipating, except marginally, in the standardization done by the elite. This leads to two distinct cuisines: a globalized and centralized one that circles around Paris, and another one of limited scope, detached and multifaceted-one that challenges that which Gramsci (1975) called the "absolute historicism" and should, for that reason, be cherished in its details. 
This way, and empirically, it is seen how the two cuisines claim the same animal in different ways; creating, for instance, the concept that there are parts of it which are of "higher quality" and others of "lower quality." The latter is destined for popular consumption. Furthermore, even sanitation guidelines will highlight this difference by prohibiting, quite often, the commercialization of certain popular parts of the same animal. Thus, the diversity which popular cuisine shows rarely invokes the national identity as long as it remains an essential expression of submissive classes. Few dishes will play that role, as is the case of the Brazilian feijoada in Brazil's first republican period. The adjective is enough to demonstrate the character of a construct. Many are the bean stews in Portugal and Brazil, but the "Brazilian feijoada" was born in Rio de Janeiro, in the early 2oth century, made with black beans (i.e., staple to both cariocas and gauchos), pork parts and sided with kale and orange.

It should also be considered that when something is "national," a symbolic barrier arises between nations. It becomes a challenging issue for the sociology of food because it requires a significant amount of detailed historical information covering an extended period of time; since no complex dish is created "out of the blue" in a given place, not to mention being given the status of a national symbol. This requires a full and silent process of confrontation and demarcation of differences among similarities in distinct countries. Moreover, it would be extremely difficult to establish the decision-making process of beyond-border food that integrates a dish, as well as the sense of yearning it raises. Wilk and Barbosa's (2012) Rice \& Beans is an excellent example of a book that makes a methodological effort to show standardization among the different culinary practices of two species associated in a single dish and in distinct countries.
Thus, in a broader time perspective, what persists is the recurrent problem of a poorly documented history on popular food, which leaves no footprints behind-except for those observed by the upper classes, which generally dwell in a different eating mindset. Colonial chronicles of Brazil, for instance, only kept a record of indigenous populations that inhabited the coast and practically nothing on what was happening in the hinterland. They wrote a lot on the use of manioc while neglecting the use of corn, which is more common in the countryside. Therefore, when questions are raised about a foodstuff common to all South-American peoples, rarely do we have accurate answers. Even the bibliography on ancient eating habits will show opposition between the locations where corn was produced in the Andean area and the Brazilian coastal area where the manioc was produced. And it is notable how the romantic history of Varnhagen (1948) has imbued in the Brazilian historiography the notion of a "Brazilianness" in manioc, with little to no mention of corn. This led to an image of cultural duality which is difficult to verify. I intend to show here the difficulty of dealing with this problem.

Within the studies on "preagricultural agriculture" (Iriarte, 2009), archeology and archaeobotany will help us discover the age of certain American foodstuffs. Corn, pumpkin, arrowroot, manioc or cassava, yam, sweet corn root, and peanut had already been domesticated in South America. In a similar way, llama and alpacas had already been domesticated in Peru; and, guinea pigs and Muscovy ducks went through the same. In the Peruvian coast and in Ecuador, clay artifacts have been found with traces of corn, pumpkin, peanuts, beans, and pacay (Vigne, 2004, p. 40). There are also recent studies in Brazil highlighting the presence of corn and other foodstuffs in the vast precolonial hinterland, which challenges the monopolistic interpretation based on chronicles from the $16^{\text {th }}$ to the $18^{\text {th }}$ century-those who charted a Brazilian eating practice revolving around the manioc.

The classic Handbook of South American Indians (Steward, 1946), explicitly in its first volume on marginal tribes, recorded the variety and spread of corn, peanut, pumpkin, and other vegetables domesticated by indigenous populations who inhabit or inhabited the Brazilian territory. Although it focuses predominantly on the beginning of the $20^{\text {th }}$ century, the book shows how a variety of domesticated and artificially-selected products were part of the eating habits of countless tribes, mainly corn, manioc, pumpkin, yam, sweet potato, beans, and peanuts. A variety of these were often mixed together. Thus, several tribes shared a common diet, supplement with the specific vegetables and animals present in their own territories.

Undoubtedly, these species were diffused by contact throughout the precolonial and colonial period, resulting in a common food source among very distinct peoples. Despite the violence and the so-called process of deculturalization, they had suffered, many species were transformed into culinary ingredients that spread throughout the West (Ribeiro, 1996). Therefore, we were led to distrust any simple explanatory scheme based on the unilateral logic of cultural imposition which other civilizations have followed. The Pre-Columbian cuisine, which shows itself as a great repertoire of adaptation to colonizers, greatly amplified the concept of utility to the West. It presented plenty of reasons for being preserved, instead of destroyed, in a way that the object of study in colonialism should be the global exchanges performed by the Portuguese, and not merely a national cuisine. About this question, see the book $A$ aventura das plantas $e$ os descobrimentos portugueses de Ferrão (2005).

Beyond the national repertoire that came to be regarded as "raw material," it is also paramount to observe the diffusion 
of techniques in food preparation. At first, many techniques were known to several pre-existing peoples, making it impossible to rank them in the way traditional sociology and historiography do. The most remarkable one is the extensive use of pottery in boiling, ever since men invented the ceramic. Others have developed in the opposite direction-from colonized to colonizer. Preservation of charque (salty, dried meat, similar to jerky), from charki quechua, initially from the meat of llamas and adapted to the meat of cattle, soon reached the Argentine and Gaucho pampas, having got to Pelotas in 1780. It later reached the northeastern region of Brazil as a substitute for the dry meat which was typically prepared there before the droughts of 1777 and has become a staple among travelers and sugar-cane workers. This unique way of preserving meat was sustained, having experienced its decline only after the invention and diffusion of the refrigeration industry. And then we can ask ourselves: would a certain technique-such as the Peruvian preservation of charque-expand and conquer a whole continent by itself or would it be followed by products of similar origin in this expanding trend?

Whoever reads Couty's report (2000) on the charque industry in the south of the continent will notice the variety of processes and adaptations that permeated its structuring, with a highlight on how this product challenged human creativity, resulting in a wide culinary field which not only raised cattle but also looked after preserving the meat so it could endure long distances, being food for great populations who could not spend their time on livestock. To this procedure, as Couty shows, national preferences are added, including taste preferences. As of today, charque still is a central ingredient in the diets in northeastern and southernmost Brazil, even though refrigerators are very common. Thus, if salting is no longer needed as a preservation method, how can we explain the exis- tence of this element if not for the taste and identity aspects revolving around it? The same happened to the Yerba mate, adopted in several countries, which present sensitive differences in agriculture, its drying and consumption, with differences in what is done in Brazil, Paraguay, Argentina, and Uruguay. In Brazil, there are even regional differences, as in the pampas and in Mato Grosso's pantanal. The same could have happened in mixed dishes where dried meat and other elements were present.

A case in point is the Peruvian locro. In 1950, Joseph de Acosta, a Jesuit, reported in his book História moral y natural de las Índias (apud Krebs, 2015) that potatoes were the main ingredient in the locro, as the high altitude did not allow for harvesting corn or wheat-chuños, however, being freeze-dried potatoes, were fitting as the basis for making "cierto guizado o cazuela, que lhaman locro.” In 1653, priest Barnabé Cobo wrote on the highlands of Peru, where "desta cecina que ellos llaman charqui, y de la carne fresca, no sabían hacer más que una suerte de olla o guisado, Ihamado locro, con mucho aji, chuño, papas y otras legumbres" (apud Krebs, 2015). Other references point to varying and mandatory ingredients, such as corn or pumpkin, with the "locro limeño" eventually incorporating the pumpkin as the central ingredient of the dish. In a few words, this stew saw its spread associated with dried meats, occasionally incorporating whatever legumes were available.

Locro is now present in several countries, varying in versions which are closer to its original Peruvian roots, being unders tood and celebrated as an Argentinian "national dish," composed of white beans and corn, as well as other ingredients, fresh meats, and enchidos, with distinct features in each province. In general, the locro Crioulo included soaked and dried corn, soaked and dried white beans, pork ribs in small cuts, cattle meat (hips) in small cubes, pig's trotters in pieces, smoked bacon, onion, common lunch meats with red pepper, yellow pumpkin, and chives. The only exception seems to be in Paraguay, where the class of locros, based on corn, differs from the class of dishes based on beans - the jopara. We can then assume, as a general hypothesis, that the following culinary ingredients "traveled together," to which populations in the new destinations added their own frequent ingredients (see Figure 1):

Figure 1. The locro

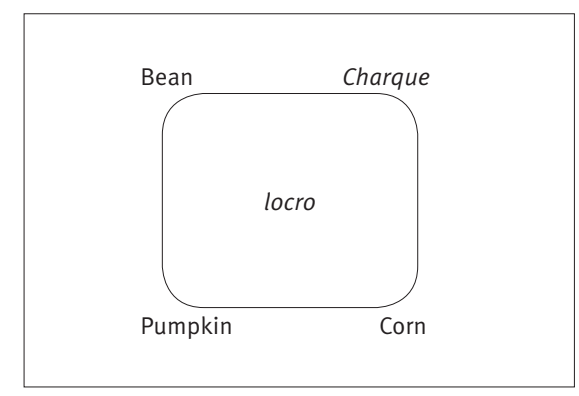

Apart from its precolonial consumption, the presence of corn in the Figure 1 is of great importance since, as we now know it, it spearheaded in Brazil and at the beginning of the $17^{\text {th }}$ century the formation of ranches and fallows along Bandeiras' routes. It was food to both animals and "negros da terra" ("black of the land," the name given to the enslaved indigenous peoples), it ensured the domestication of pigs and poultry, as well as diversifying and multiplying settlers' recipes and dishes. We can then see in the locro and other similar dishes a traveling "culinary solution" which was able to establish roots in a vast colonial territory in South America, having become a popular dish with several qualities, as a "full meal" or as a unity capable of absorbing into a single legume-based stew a variety of locally produced meat coming from Iberian animals. It is also important to note a similarity to the "olla o guisado," that is, its technical approximation to European cuisine.

Would it be the case of asking ourselves why the charque "traveled" across Brazil without "companions"? And, proba- 
bility-wise, would it be hard to assume that a similar dish, combining four ingredients or more, might appear far from its historical origin? It is true that in Brazil there is no locro, with the exception of Pantanal, allowing us to speculate on a possible "contamination" via Andes cuisine. However, we do have a similar dish, put together in the countryside of Bahia in the first half of the $20^{\text {th }}$ century. It is the pintado (Portuguese for "spotted"): "equal parts of beans and crushed corn, salt, black pepper, cumin, garlic and crushed onion, all cooked with bacon in water, to which are added charque, pork and ham hock-thoroughly crushed so no bone marrow is lost" (Dória, 2014, p. 199).

Furthermore, though named differently, it is a relative of the locro family, lacking only pumpkin to be "genuine." It should be noted that the relation between beans and pumpkin in the "Northeastern" or "pernambucana bean stew" is very commonalmost mandatory. In other words, they all belong to the same family of "beans" or "porotos" laid on the table. It is here that the researchers, mainly anthropologists, will have to decide if they are in fact of a "diffusion" or a "parallel invention," things which result in theoretical and methodological paths that are quite diverse. And if the hypothesis of a historical or cultural contact between Bahia's countryside and Peru is discarded-which is not very likely, due to the diffusion of complex elements as in a recipe-the probability of a parallel invention will depend on the assumption that the ingredients which are an integral part of this invention share an equivalent participation (homology) in both culinary clusters. That would already be an interesting question, given that culinary analyses tend to prioritize analogies, not homologies. However, according to Boas' perspective (1966), we would have to find the intermediate types if we wanted to be in accordance with the scientific method. "It seems to us that the uniformity of ear- ly patterns cannot be proved. By analogy of the phenomena recently mentioned, we may rather infer diversity of early patterns" (Boas, 1996, p. 294).

In Brazil, as is the case in Peru and other countries next to the Andes strip, where domestication was shared even before precolonial times, elements like beans, pumpkin, corn, peanut-all equally domesticated-belonged to several cultures spread across the territory, with limited exchange, before being forced into an undesired and integrating coexistence by colonization. Thus, we can imagine that the accumulation and association between charque, pumpkin, beans, and corn have been relatively recent if compared to the Andes. Anyhow, charque, beans, corn, and pumpkin have been enshrined as privileged, popular foods in the colonial system, as in a convergence between taste preferences of king and peasant, mainly in the form of a stew. The colonial "pot au feu," which comprises everything, also approximates coloniz ers and colonized through the sharing of the same technical procedure of pot cooking. While pot cooking in Europe helped develop "vegetable garden legumes," among us, Americans, this garden depended on the improvement of a sedentary form of agriculture that was not always present. Omnipresent, however, were beans, corn, and pumpkin, even if not originally surrounded by the medical "Galenic values" which imposed the existence of a vegetable garden to colonizers' eating standards, up until the late $18^{\text {th }}$ century.

Maybe the central element in these culinary solutions called locros is the way they meet the needs of the poor. Expressions like "ganarse los porotos" or, in Brazil, "not having a bean tree," speak thousands of words when evidencing the relationship between poverty and this fabaceae. The rustic association between beans and corn, or beans and pumpkin, is blatant not only for the botanic features (beans "fertilizing" the soil) but also for cultural ones, as in the association between "cold" ingredients and "warm" ones. Pumpkin and rice, for instance, are regarded as "cold" food, finding their balance with beans, garlic, and pork fat, which are "warm" ingredients. This classification was European, not native. When it classifies native raw material, a "bridge" is buiIt between colonizer and colonized. Thus, we have the fossilization of all the elements that compose these dishes-locros and pintado-as a food source available to the poor captive populations in the vast colonial system. In colonialism, at least two types of land relations were developed: intensive exploitation of plantations and subsistence agriculture; around the plantations, the poor feed themselves with beans, pumpkin, corn, and dried meat, and sometimes with pork or chicken.

Generally, the use of beans is similar to the use of pasta in Italy: from the ancient lasagna shape (what was known to be the topping of a "pie"), new shapes branched out in different locations, with different cuts and "fillings" ("sauces"), also relative to their locations (Sabban \& Serventi, 2002). When the unification of Italy started, this diversity had already been configured and served many times later as a testimony to the cultural vitality of local and regional features. In other words, the Italian pasta is universalized at the same time it is particularized. Among us, many species and hundreds of beans are named after local expressions, seeming to be entirely distinct types, although they only demonstrate the central participation of beans in diets of all corners. Linguistically, it is possible to see how other food components, such as the corn adopted by precolonial guaranis who dwelled across north and south, were seen as diverse in similar functions: canjica, curau, mungunzá, pamonha, quirera/xerém are more than synonyms-they have developed as an expression of isolation where common food solutions came to light throughout the centuries. 
Along these lines, would we be willing to recognize the bean-pumpkin association, sometimes with corn, and together with meat, as the staple of our most enduring tradition? Given that the urban popularization of rice only happened after the Portuguese Court came to Brazil in the early $19^{\text {th }}$ century, would it be even more of a staple than rice and beans? The widespread appeal of beans and pumpkin and the close relations between corn and domestic creations will transform this set of products and popular familiarity into a springboard for related food solutions, in varying combinations and present in large portions of a territory. However, admitting to this also means renouncing the Treaty of Tordesillas, or, more recently, the borders in South American nations, and accepting that the locro, taken as an example here, suggests more of the continuity of this immense territory, rather than its discontinuity. The study of our culinary arts, however, is heavily taxed by "nationalism," blurring the image of the forest where one sees the tree. Exchanges between precolonial peoples are part of an obscure subject in our history and anthropology. Moreover, different food paths based on similar raw materials show that the analysis on the culinary must consider the cultures and history of dish formation, rather than just focusing on the simple study of agriculture as a universalizing force and commodity producer.

Besides the locro, others could be added here to help "measure" the distance which a popular dish may cover throughout the colonial period, at which time the importance of recipe books is little or nonexistent. We all know that the couscous, whether from semolina or steamed, arrives in Brazil in the Captaincy of São Vicente in the $17^{\text {th }}$ century. There, semolina from durum wheat, from Maghreb, is replaced by corn flour. Afterwards, this same association-corn flour and steam cooking- will conquer the Brazilian countryside where corn was always present, with its occurrence being verified from the northeastern backcountry and part of the Amazon rainforest to the lowlands (pampas), where the exquisite cuscuz missioneiro (Portuguese for "missionary couscous") is found, in the border between Brazil and Argentina. Its diffusion is a result of expeditions from Bandeirantes and troops articulated with São Paulo.

Cases like these point to the necessity of reviewing the "canonical" theses that defend the formation of a Brazilian cuisine deriving from a simplistic miscegenation of European techniques and ingredients from colonized peoples. As a hypothesis, we may assume that certain examples of diffusion happened during colonialism; others, less noticeably but equally explicable, require a more profound way of perceiving historical processes, including the precolonial ones that allowed for the exchange between cultures which colonialism itself separated and destroyed. Thus, it makes no sense to believe that stews, broadly speaking, have originated from Portuguese dishes, once cooking techniques with water were standard to the Portuguese and other peoples subjugated by them. At the same time, the territorial dynamics of the locro, or even couscous, show preserved forms as "dishes," traveling across time and space, or "parallel inventions," and these can only be explained by approaching history from a different perspective.

In order for a comprehensive perspective to be developed in food anthropology and historiography, it is important to abandon the sociopolitical division of the culinary that opposes regional, national, and international spaces, as if it were the State deciding on the popular food-which it has never done-and not only abandon the symbolism of eating as a "nation" or "region"something which it has frequently done.

\section{REFERENCES}

Boas, F. (1966). Evolution or diffusion? In F. Boas, F., Race, Language and Culture (1924). New York, NY: The Free Press.

Bornand, I. M. A. M. (2012). El ingrediente mapuche. De la colina al Estado-nación, Departamento d'Antropologia Cutural i História d’Amèrica, Universitat de Barcelona, Barcelona.

Cascudo, C. L. (1997). Antologia da alimentação no Brasil. Rio de Janeiro, RJ: LTC.

Couty, L. (2000). A erva mate e o charque. Pelotas, RS: Seiva.

Dória, C. A. (2009). A culinária materialista. São Paulo, SP: Editora Senac.

Dória, C. A. (2014). Formação da culinária brasileira. São Paulo, SP: Três Estrelas.

Ferrão, J. E. M. (2005). A aventura das plantas $e$ os descobrimentos portugueses. Lisboa, Portugal: Instituto de Investigação Científica Tropical.

Freyre, G. (1946). Casa grande e senzala: Formação da família brasileira sob o regime de economia patriarcal. Rio de Janeiro, RJ: J. Olympio.

Gramsci, A. (1975). Quaderni del cárcere. (Quaderno 25, 1934), Torino, Italy: Giulio Einaudi Editore.

Iriarte, J. (2009). Narrowing the gap. Exploring the diversity of early food-production economies in the Americas. Current Anthropology, 50(5), 677-680. doi:10.1086/605493

Krebs, M. (2015). Historia de los orígenes del locro. Retrieved from http://www.historiacocina. com/historia/articulos/locro.htm

Martínez-Hernáez, A. (2011, Julho/Setembro). El dibujante de limites: Franz Boas y la (im) posibilidad del concepto de cultura en antropologia. História, Ciências, Saúde Manguinhos, 18(3), 861-876.

Ribeiro, D. (1996). Os índios e a civilização, A integração das populações indígenas no Brasil moderno. São Paulo, SP: Cia das Letras.

Sabban, F., \& Serventi, S. (2002). Pasta: The history of a universal food. New York, NY: Columbia University Press. 
Steward, J. (1946). Handbook of South American Indians, vol. 1, Washington, DC: Smithsonian Institution.

Tilly, C. (1992). Coerción, capital y los Estados europeos 990-1990. Madri, Spain: Alianza Editorial.
Tonnies, F. (1961). Gemeinschaft and Gesellschaft. In T. Parsons, E. Shils, K. D. Naegele, \& J. R. Pitts (Eds.) (pp. 191-201), Theories of Society. Foundations of modern sociological theory, New York, NY: The Freee Press.

Varnhagen, F. A. de (1948), História geral do Brasil: Antes da sua separação e independência de Portugal. São Paulo, SP: Cia Melhoramentos.
Vigne, J-D. (2004). Les origines de la culture: Les débuts de l'élevage. Paris, France: Le Pommier.

Wilk, R., \& Barbosa, L. (2012). Rice \& Beans: A unique dish in a hundred places. London, UK: Berg Publisher 